\title{
Shusaku Endo: from the Silence of the East to the Silence of God
}

\author{
Rodica Grigore $^{1}$
}

This essay examines several topics related to the problems of faith and, above all, of how people experience the limit(s) of their consciousness and of the world they live in. The main concern is to show how these issues are expressed in modern literature and especially within the specific field of modern Japanese literature. Therefore, our demonstration is stressed upon Shusaku Endo's work, taking into consideration his unusual personal experience within Christianity. The author himself often spoke of Christianity as an ill-fitted suit for his Japanese frame. In this respect, we may state that what Endo inherited rightly was his vision of the world, a sacramental worldview that sees human action within the grand narrative of God's redeeming activity in the world. After all, what Shusaku Endo rebuffed in European Catholicism was not the idea of Catholicism per se, but some particular modes of thought and cultural assumptions about strength and weakness. [Article copies available for a fee from The Transformative Studies Institute. E-mail address: journal@transformativestudies.org Website: http://www.transformativestudies.org (02010 by The Transformative Studies Institute. All rights reserved.]

KEYWORDS: Faith, Catholicism, Limit, Death, Tragic, Modern Japanese Literature, Christianity, Multiculturalism, Religion, Sacrifice.

\footnotetext{
${ }^{1}$ Rodica Grigore, Ph.D., is a lecturer in Comparative Literature at Lucian Blaga University in Sibiu, Romania. She is the author of three critical studies: Despre cărţi şi alţi demoni [Of Books and Other Demons], 2002 and Retorica măştilor în proza interbelică românească [The Rhetoric of Masks in Romanian Modern Fiction], 2005 and Lecturi in labirint [Readings in the Labyrinth], 2007. She has also translated into Romanian the essays of Octavio Paz, Copiii mlaştinii [Children of the Mire], 2003, the poems of the Colombian writer Manuel Cortés Castañeda, Oglinda celuilalt [The Mirrored Other], 2006 and a collection of novellas and short stories of the American writer Andrei Codrescu, Un bar din Brooklyn [A Bar in Brooklyn], 2006. Since 2005 she has been coordinating the anthologies of The International Theatre Festival of Sibiu, Semne [Signs, 2005], Impreună [Together, 2006], Next [2007] and Energii [Energies, 2008]. She has published numerous essays and critical studies especially on modern literature in several Romanian literary magazines: Cultura, Contemporanul, Euphorion, Saeculum, Scrisul Românesc, Viaţa Românească. Recently she has authored a short anthology of Romanian poetry published in Mexico, Spain and Venezuela. Address coresspondance to: Rodica Grigore, Lucian Blaga University of Sibiu, Faculty of Letters and Arts, Victoriei Blvd. 5-7, Sibiu, Romania; e-mail: rodica_grigore@yahoo.com.
} 